\title{
準備委員会企画シンポジウム 4
}

\section{“Nothing about us without us!”がもたらすもの 障害者権利条約から見る特別支援教育}

Changes Brought by "Nothing about us without us!"; Reconsidering Special Needs Education Through Convention on the Rights of Persons With Disabilities

Hiroyuki Arikawa, Tadashi Kouyama, Norio Syuusa and Toshiyuki Iwanami

企画・司会有川宏幸 (新潟大学) 話題 提 供神山忠 (岐阜特別支援学校)

話題提 供 周 佐 則 雄 (ナマラエンターテイメント) 話題提供岩 浪 敏之 ( $\mathrm{K}-\mathrm{B} \quad \mathrm{O}$ X)

\section{企画趣旨}

2006 年，障害のある人の尊厳と権利を保障するた めの国際人権条約である “Convention on the Rights of Persons with Disabilities” (以下, 「障害者権利条約」と する）が採択された。日本は 2007 年にこの条約に署名, 2014 年 1 月に批准書を国連に提出し，140 番目の締約 国となった。この批准までの間，国内法の整備が進め られ，2013 年，「障害を理由とする差別の解消の推進 に関する法律」が可決，成立 (平成 28 年 4 月 1 日施行) するに至った。この法律は, 障害者基本法第 4 条の 「差別の禁止」を具体的に規定したものであり，「合 理的配慮（reasonable accommodation）」をしないことは， 「差別」にあたることを明記している。

「障害者権利条約」では「合理的配慮」を，「障害者 が他の者と平等を基礎として全ての人権及び基本的自 由を享有し，又は行使することを確保するための必要 かつ適当な変更及び調整であって，特定の場合におい て必要とされるものであり，かつ，均衡を失した又は 過度の負担を課さないもの」としている。

今, 改めて障害者を取り巻く社会の在り方について 議論が起こっている。「障害者権利条約」の基本的考 え方に従うと，「合理的配慮」の提供にあたっては, 障害のある人達と, その周囲の者達が, 彼らの権利の 行使を持続可能とする社会構造を, 共に構築していく ことが求められている。

Nothing about us without us! (「私たちのことを,私た ち抜きで決めてくれるな!」)。これは，1960 年代にアメ
リカで始まった自立生活運動（Independent Living Movement）の中から出てきた言葉であり，障害者権利条約 の制定過程においても，障害当事者の間で口及に叫ば れた重要なスローガンである。

さて，このスローガンに私たちはどれだけ耳を傾け てきたのであろうか。また心理学は, 彼らの「特異 性」に焦点を当ててきた。

一方で，障害当事者は，こんな我々の姿に何を見て きたのであろうか。それを聞き，これからの特別支援 教育について一度考えてみたいと思う。これが, 本シ ンポジウムの企画主旨である。

\section{学習障害の立場から}

\section{1. 略歴}

1965 生まれ。高校卒業後, 陸上自衛隊に入隊。夜 間短期大学に通いながら，教員免許取得。中学校，小 学校教諭を経て, 現在は，特別支援学校教諭。

学習障害 (読字障害)。「文字を文字としてとらえる」 「文字の音韻処理（音読）をすること」に困難がある。

\section{2 、私の障害とは}

私の障害はディスレクシア (読字障害) です。文字を， 文字としてではなく，壁紙に描かれた幾何学模様に感 じます。「図と地の関係の処理」も難しい。授業など で，資料を見せられて「ほら，○○がいるよね」と問 われても，それがどこに隠れているのかがわからない。 他にも, 縦書きの文章がどうしても読めない。教科書 は縦書きで書いてある物が多いので，これを読みなさ いと言われると，激しくうねる感じがしてきました。 こうなると，もう立っているのがせいいっぱいでした。 小学校の高学年から中学生の頃には, 「目が縦に並 んでいたら，縦書きの文字も読めるようになるだろう か」と考えていました。目が縦になっていれば，周囲 
が，どの様に思うかと言うことはもちろん想像できま した。でも，それ以上にみんなと一緒に学べるのなら， それでもよいと思っていたのです。

私の脳が，文字として認識したものについては，拾 い読みをすることは可能です。でも，文字情報から音 を想起することはとても難しい。私にとっての第一言 語は,「図」です。文字の意味も, 字面で理解し, 頭 の中で図とのマッチング作業を試みます。「あっ，あ の字面は, あの図の事だ」と, 図とのマッチング作業 をすれば意味は汲み取れます。

\section{3. 学校での支援}

小学校の時にこんなことがありました。新しいクラ スになって, 新しい班も決まって，ちょっと一安心し ていた時に, 班に 1 冊ずつ新しいノートが配られまし た。先生は,「このノートに, 自分の思っていること を，それぞれに書いて，それを班のみんなに回しま す」と説明しました。私は「そういうノートをするの か。頑張ろう」と思いました。その時, 先生は思い出 したように，こんなことを付け加えたのです。

「そうそう，神山君の班の人は，みんな“ひらがな” で書いてあげてね」と。私は，その言葉を聞いて「も う, 教室から駆け出していきたい, それができないな ら机の下にもぐりたい」，そんな気持ちになりました。

クラスの 4 分の 3 は，私のことを知りません。私を 知らない友達に向かって, 早々に「神山は, 勉強でき ん奴やぞ」と言われたようなものなのです。もちろん， 先生にはそんな意地悪な気持ちは微塵もなかったはず です。でも，私にはとても恥ずかしいことだった。良 かれと思ってやったことでも, 当事者から見ればそう ではないこともあるのです。

「ひらがな」ばかりの文章はとても読みにくい。例 えば，「あるみかんのうえにあるみかんをもっていっ てね」と言う一文があったとします。ひらがなだけだ と,よくわからない。でも,「アルミ缶の上に在る蜜 柑を持って行ってね」「アルミ缶の上にアルミ缶を 持って行ってね」と, カタカナ, 漢字, ひらがなを混 ぜて書いてもらえれば，私にはこの問題は解決します。 学校では，なぜか「勉強ができない子には，“ひらが な”で」と言うことが配慮の鉄則のように言われるこ とがあります。でも，かえってわかりにくいと言うこ とが実は多くの場面であります。

他にも, 小学校の教科書には, 習った漢字と, 習っ ていない漢字の関係で,「ひらがな」と漢字が混ぜ書 きになっている。例えば「努」が既習でなければ「努 力」は,「ど力」と書かれる。こうなると, 私の場合
は字面と図のマッチング作業はできません。私にとっ ては, 初めから熟語のように字面で示してもらう方が よいのです。さらに色を変えてふり仮名をふってもら えると，もっと助かります。「なぜ，ふり仮名に色を 付ける必要があるのか」とよく問われます。私は, ど こまでが漢字で，どこからがふり仮名か，わからなく なってしまいます。一生懸命に字を覚え, 漢字テスト に臨んだら，ふり仮名の部分も合わせて覚えていたの で, そのまま解答してしまった。当然, 誤答です。 「ひらがな」と漢字部分の色が変わっていれば，別々 のものとして区別して覚えることができたのです。

他にも, 文字がぎっしりと詰まった文章は, 読むこ とが難しい。「拡大コピーをすれば読みやすくなるか ら」と拡大コピーを渡されることがあります。でも, 単純拡大で資料を渡されても, 重い, 大きいだけで扱 いにくい。私の場合は，余白や行間，文字間，書体の 関係で読みやすさが変わってくるのです。

教室の中には, 実際には, 様々な学び方を必要とし ている子ども達がいます。でも, 教員の中には学び方 には唯一の方法しかないと思い込んでいる人がいます。 そして, この方法で勉強しなさいとプレッシャーをか けている。そのように感じています。

\section{4. 支援ニーズと学校}

平成 14 年に行われた文部科学省の調査では, 通常 学級になんらかの配慮を必要としている子どもが, $6.3 \%$ ることが明らかになりました。その後，何を 始めたのかと言うと, 手厚い教育の名のもとに, 切り 離しを行ったのではないかと思います。実際，10 年 たって，もう一度調査をしたら，今度は $6.5 \%$ になっ ていた。これを, ほんの $0.2 \%$ の増加と見るか, 従来 は通常学級にいた子どもを切り離したうえでの $0.2 \%$ の増加とみるか，いろいろと考え方はあると思います。 私は，後者なのではないかと思っています。これに対 して,さらにまた切り離しをしてしまったらどうなる のでしょうか。ふるいの目は, さらに厳しくなってい くのではないでしょうか。

確かに, 切り離しをすることで, 校内でのトラブル 等は少なくなって, 一見やりやすくなったのかもしれ ません。でも指導力は，明らかに低下しています。

さらに子ども達同士も, 様久な個性と触れ合う場を 失っていきます。学びの輪は, どんどんと小さくなっ ていく。結局はより脆弱な社会になっていく気がしま す。

バランスの良い発達を目指すことで, 型に収まる子 どもを作っている。いびつで尖ったままの子どもがい 
ても，よいのではないかと思います。でも，いびつに 尖っているところは削り，足りないところをなんとか 埋めようと言うことばかり考えている。「尖っていて もいいよ」,「あの子のあれって, すごいよ」,「あの子 にこの仕事まかせたら, 凄い仕事してくれるよね」, そんな社会, 集団の方が, より豊かなのではないで しょうか。

私たち大人が，子ども達に「よい子」に育って欲し いと思っているのは確かです。でも，その「よい子」 とは，実は大人にとって「都合のよい子」となってし まってはいないでしょうか。本当は，トマトなのにも かかわらず，「メロンになれよ，メロンになれよ，メ ロンになれば，みんなに高く買ってもらって重宝がら れるよ」と言って, トマトにメロンの肥料をあげ, メ ロンの温室に入れて育てようとしている。これも当事 者の声を聞けば，「苦しいよ」と言っていることが理 解できるはずです。理解した上で，その子に合う環境 を整えてあげる。トマトならば，トマトにしかできな い人生を送る方が，実は何倍も豊かな人生になるよう な気がします。

\section{5 . 社会モデルと生きづらさ}

わたしの転機は, 自衛隊に入った時です。それまで は, もう劣等生でしかなかった。でも, 自衛隊に入っ てみると，文章による教育は本当にごくわずかでした。 口頭で教えられ，そして実物を操作するという学びで した。私にとって，その学び方は合っていました。お かげで，いろいろな任務を任せてもらえ，多くの資格 も取れました。ズタズタだった私の自尊感情を取り戻 すことができました。成人式も隊の中でやってもらい ました。その時に「今までの 20 年を振り返り, そし て今後どう生きていくかを考えなさい」という話があ りました。それまでの私は「こうなったのは親のせい や」「先生のせいや」「教育のせいや」と，人のせいに ばかりしてきました。この先どうしていくかを考えた 時に，「自分が，勉強のわからない子の気持ちのわか る教師になったらよいではないか」。そう思うように なりました。

それから, 夜間の短大に通いました。短大は当然, 文章による教育でした。でも「この方法で勉強しなさ い」と限定されなかった。おかげで, 自分の得意な方 法や，様々なツールを使うことができました。教員免 許もとることができ，今に至っています。

教員になってもいろいろありました。ストレートで 大学を出て, ストレートで採用された先生と, 採用ま でに 3 年かかった私が同じ学校にいる。1 か月たって,
給料を見せ合った。その先生は，年齢がかなり若かっ たのだけれども，給料はとてもよかった。そこで事務 の人に聞いたわけです。すると「あなたの方が年齢は 上だけれども, 夜間の短大卒で二種免許です。だから 給料表はこちらになる。あの人は, 四年制の教育学部 を出て, 一種免許を持っている。だから年齢は若いけ れども, 給料表はこちらになる」と言われました。こ の時,「そうか, 今の社会のシステムって, 制度を 作っている人が生きやすいようにできているのだ」と 感じました。だからと言って, 学校教育が社会のシス テムを作る側に特化したものになってはいけません。 今の社会システムのままでは, 障害や, 生きづらさを 感じる人は多いままだと思います。社会モデルによる 障害者は，少なくないのです。

\section{肢体不自由の立場から}

\section{1. 略歴}

\section{周佐則雄}

1975 年生まれ。脳性麻痺。10 年前に, 養護学校時 代の先輩, DAIGO 氏と再会。お笑いコンビ「脳性マ ヒブラザーズ」を結成, 地元で活動を始める。2010 年, NHKのEテレ「SHOW-1 グランプリ」で, 初 代グランプリを獲得。

\section{2. 知的障害児クラスに入学して}

私は, 小学校から高校まで養護学校へ入っていまし た。実は私, 6 歳の 4 月から学校に入っていません。 12 月に入り, そこで小児療育センターの中にある養 護学校に入りました。学校は, 知的障害のある子ども のクラスと, 身体障害のある子どものクラスに分かれ ていました。私は, 当時, 言葉も遅く, コミュニケー ションも十分にとれませんでした。そのため「扔勉強 はできないのではないか」ということになり, 知的障 害のクラスに入ることになりました。でも，何日かみ んなと勉強していくうちに, 「この子, 本当は勉強が できるのではないか」と言う人たちが出てきました。 その時の担任の先生が私に「君は今のクラスでこのま ま勉強をつづけたい？それとも，もう1つの方のク ラスで勉強したい? 」と聞いてきました。当時, 仲の 良かった友達が身体障害クラスにいたので,「もう 1 つのクラスで勉強がしたい」と言いました。それで身 体障害のクラスに行くことになりました。今の自分が あるのは, その時の友達と担任の先生のおかげかなと 思います。それがなければ, 脳性マヒブラザーズとし ての活動もなかったと思います。

小学校 4 年生の時に, 一度, 地元の普通小学校に入 
れるかもしれないということになりました。ですが, まだ当時の学校は, バリアフリーじゃなかった。私は, 動きも遅く, なかなか教室にたどり着けない。おまけ に, 勉強もそれほどできなかった。結局は, そのまま 高等部まで, 養護学校にいることになりした。

小学部, 中学部の頃は, 学力ごとにクラス分けがさ れていました。違う学年の友達とも, 一緒に勉強がで きたのは良かったのですが，1つ悲しいことがありま した。後輩と一緒に勉強していた時のことです。私が 中学 3 年生で, 後輩は中学 2 年生でした。でも後輩の 方が学力は高く, 彼は中学 3 年生の勉強していました。 そして私は小学 6 年生の勉強をしていたのです。これ には，とても悔しい思いをしました。

また養護学校は, 人数が少ない。そうなると, 普通 の学校と違って，さぼることができない。遅刻したり， 居眠りしたりというドラマのようなことができないの です。試験も学力がみんな違うわけですから, 試験問 題も違う。カンニングなどできないわけです。ちゃん と勉強しなければなりませんでした。

\section{3 . 高等部を卒業して}

高等部を卒業後, 1 年間, 職業訓練を受けることに なりました。そこで私は, 生まれて初めて健常者とし て扱われることになります。でも, 健常者扱いされて も，障害はあるわけです。すると「あなたは，障害者 だからこういうことができない。でも, 健常者はこう いうことができる。だから，あなたも，それができる ようにならなければいけない」と言われたのです。養 護学校だと, マイペースでいることが重視されます。 でも, 訓練校に入ると社会に合わせることを求められ ます。当時, 私はコーヒーが飲めなかった。すると

「あなたは商談先でも, 絶対にクリームパフェを食べ るでしょう。でも, それではいけない。だから,コー ヒーを飲む練習をしなさい」と言われました。しかも 砂糖なしで。

養護学校では試験は形だけでした。けれども, 就職 試験は形ではなく，実際に受けるものです。これも訓 練校で, はじめて気づかされたことでした。その後, 20 社の入社面接を受けましたが，すべて不合格にな りました。

\section{4. 就職に失敗して}

不合格の通知には「この度はご縁がありませんでし た」と書かれています。私は「ああ, “この度”とい うことは, 次は合格通知がくるってことなんだ」と本 気で思っていました。すると周囲の人たちは「来ない よ。これは, 次は来ないと言うことなんだよ」と言う
のです。それを何回か経験することで, 段々と「これ が社交辞令というものなんだな」とわかってきました。 21 歳の頃のことです。「健常者って, なんて嘘つきな んだ」って思ったのを覚えています。

こんなことが続き，結局，作業所に入ることになり ました。でも作業所の生活は私にとっては退屈なもの でした。また，小さい頃からアニメや漫画が好きで, どうしても声優になりたいと言う夢がありました。そ こで声優のオーディション情報を探していました。あ る時, 地元ラジオ局が「アマチュア大募集」という記 事を出していたのです。私は「性格があまちゃんだか ら応募できる」と早速応募しました。

面接で話をしていると「君は, アマチュアの意味を どう捉えていますか」と聞かれたのです。私は「アマ チュアって, 自分に甘い人達のことを言うのですよ ね」と本気で答えました。笑われました。「アマチュ アというのは，お金を払うまではいかないけれども， その技術がある人のことを言うのだよ」と教えられた のです。「ああ,また勘違いしてしまった。でも, こ の際, ラジオ番組に出られるのだからいいや。そのう ち失敗するかもしれないけど, 挑戦しょう」と思い, ラジオの仕事をすることになりました。

\section{5. 脳性マヒブラザーズとして}

今活動している脳性マヒブラザーズについてお話を したいと思います。新潟に，心身障害者パフォーマン ス集団「こわれ者の祭典」というものがあります。今 から約 10 年前, そこに私も入っていました。そこで 再会したのが, 私の学校の先輩である DAIGOくんで す。この DAIGO くんが, ある時, お笑いコンテスト に出たいとメンバーの全員に声を掛けていました。け れども, 誰も反応しない。かわいそうだなあと思い 「1回だけならいいよ」と始めました。それからもう 10 年です。だまされてしまいました。

でも，おかげでNHK Eテレの『バリバラ』とい う番組に出させていただきました。そこでShow-1 グランプリの初代チャンピオンにもなれました。レ ギュラー番組では, 新潟から大阪まで「千人笑わす 旅」という企画にも出ることができました。

この番組で大変だったのは, NHK スタッフが, 私 たちが障害者だということを完全に忘れていたことで す。番組では, 朝早くから夜遅くまでロケをします。 脳性麻痺があるので, どうしても動きは遅くなってし まう。ある日，深夜 1 時まで撮影をしました。その後， 遅い夕食を済ませ, お風吕に入り, ようやくベッドに 辿り着いたら，もう朝になっていた。そんなことがそ 
の後もよくありました。

それでも, 脳性麻痺という障害があったから，こう いう仕事ができたのかなとも思います。昨年は北川景 子さんが主演の『抱きしめたい』という映画にも出演 することができました。

\section{6. 障害と個性}

最後に, 学校や, 脳性マヒブラザーズの経験を通し て，私が感じたことをお話ししたいと思います。

今，社会では障害は「個性」とやたらと言われます。 でも私は，生まれつき脳性麻痺があるので，障害を 「個性」と言われると, よくわからなくなってしまい ます。この「個性」とは，私の「性格」を言われてい るのか,それとも私の「障害」のことを言われている のか，それがわからなくなる。「あなたの個性だから， ありのままでいいよ」と言われると, 私の「性格」か らすると「なんだ，何もしなくてよいのか。勉強も， 訓練もしなくてよいのだな」と思ってしまう。

また，学校や施設の中にいると，世間のことが別世 界のことの様に感じています。まるで映画やテレビの 世界の様な感じなのです。歩いている人を見ると「な んか芸能人がいっぱい歩いている」という感覚になる のです。そんな中で，みなさんに「頑張っているね」 と言われる。けれど，こう言われると「あなた達と， 私たちとは別世界にいるけれど, 頑張ってね」と聞こ えてしまいます。

今，芸人として壁にぶち当たつていることがありま す。それは，自分たちはこれまで過程を褒められるこ とはあっても, 結果を求められてこなかった。今，相 方とふたりで稽古をしていても「俺こんなに頑張って いるのに，何が悪いの」と言われてしまう。でもお笑 い芸人にとっては，過程をどれだけ頑張ろうとも，結 果がすべてです。「結果を出さないとダメだ。結果が 出て初めて仕事がもらえ, テレビにも出られる」と話 しています。

「学校でも, 過程だけを襄めるのではなく, ちゃん と結果についても教えてもらえていたら，こんな苦労 はしなかったのに」と思っています。

\section{アスペルガー症候群の立場から}

\section{1. 略歴}

1975 年生まれ。35 歳の時にアスペルガー症候群と 診断される。大学生活に馴染めず, まだら引きこもり も経験する。現在，K-BOX で表現活動を行っている。

\section{2. 気付かれない生きにくさ}

私の障害, みなさんにはどのように見えますか。 きっとわかりにくいと思います。私の障害はアスペル ガー症候群です。両親が共働きだったため, 母方の祖 父母に預けられていましたが，その頃の話を聞くと， まったく「お母さん，扮さん」とは言わなかったそ うです。母と離れる時でさえも，泣いたりしない。父 や母がいなくてもまったく平気。そんな子どもだった そうです。

私は絵を描くことが大好きでした。小学校の頃は, 自由帳に好きなマンガの絵を描いたり, 迷路などを描 いたりして過ごしていました。サッカーや, 野球など もやっていたのですが，「みんなでやるスポーツの楽 しさ」というのがよくわからなかった。野球の楽しさ を知ったのは，テレビゲームで野球ゲームをするよう になってからです。

学校で困ったことと言えば，給食を食べるのがとに かく遅かった。でも, これには理由がありました。人 と話していると, 食べることが出来なくなる。私は, 同時に 2 つの活動をすることがとても難しいのです。 結局, 食べることが遅くなってしまう。それでも, 給 食が遅いということくらいでは, 外から見ると特に配 慮が必要だということにはならなかったようです。

ただ，私自身は，子どもの頃から，人と一緒にいる となぜか違和感がありました。とにかく周囲の話につ いて行けない。笑うポイントがわからない。どこで人 の話に加わってよいかもわからない。なので, 話は常 に聞く一方でした。「ただ，そこにいる」，そんな感じ の子どもでした。周囲にも, 学校の先生にも, 困って いるようには見えないのです。

この状態は大人になっても続きました。大学に入学 して 1 年, 寮生活をしていました。ここでの集団生活 に，そうとうなストレスがかかっていました。そのス トレスが, どんどんと溜まっていく。そして 2 年生の 時には, 引きこもりになってしまいました。大学の授 業にも出席できなくなってしまったのです。それでも, なんとか大学は 4 年で卒業しました。でも就職活動は せずにおり,この頃に, 金銭トラブルなどにも巻き込 まれてしまいました。日に日にうまく行かないことが 多くなってきたのです。こんな状態になっていても, 周囲からの支援はありませんでした。特に家族からの 理解が得られなかったことは辛かった。

\section{3 . 支援者との出会い}

実は私は病院で診断を 2 回受けています。1 回目は, 金銭トラブルに巻き込まれ, 裁判のために病院で診断 
を受けることになったときです。10 年前です。 2 週 間おきにカウンセリングや，いくつかの心理テスト， 脳の MRI などを受けました。限りなく精神疾患があ ると考えられるが，診断はつかない。いわゆる心身耗 弱状態とのことでした。

その後， 8 年前に引きこもりを支援するセミナーを 自分で見つけ，そこでようやく様々な支援を受けるこ とになりました。コミュニケーションセミナーを受け たり，履歴書の書き方を教わったり，面接や電話の応 対について学びました。そのセミナーの講師だった方 たちとは，その後も長くお付き合いさせていただいて います。

この頃に受けたセミナーの中で, 発達障害について 知りました。テレビなどの特集番組も気になり，「自 分もこの障害に該当するのではないか」と思うように なりました。親にも，それを伝えてはみたのですが， なかなか理解は得られませんでした。そこで発達障害 支援センターの方に，相談をしました。それをきっか けに再度，様々な検査を受けることになり，ようやく 35 歳のときに，今の診断を受けました。

現在は，K-BOX というところで表現活動をしてい ます。新潟には「こわれ者の祭典」という様々な生き づらさを抱えた人たちが，自らの生きづらさをスト レートに訴える活動があります。9 年ほど前にはじめ て，それを見ました。生きづらい経験を「こんなに， ストレートに表現していいのか。こんなに恥ずかしい ことをオープンにする人たちがいるのか。自分も，こ んな風に表現したい」，そう思うようになりました。 私は，絵が好きなので今は絵を発表したり，時々お笑 いをしたりと，自分なりの表現活動をしています。

\section{4 . 教育について}

最後に, 今日は教育心理学会員の集まりということ で，1つ，お伝えしたいことがあります。この前，テ レビで「子どもが世界で一番幸せだと感じている国」 ということで，オランダの教育について紹介されてい ました。オランダでは, 小学校のうちから, 子ども達 は好きなことを学んでいる。もう少し，これについて 学びたいということがあれば，もう 1 年，その教科を 学習してもよいそうです。

でも，日本の教育には，こうした自由はありません。 大人が，工場で大量生産された既成の服を，無理やり 子ども達に着せている。そんなイメージが日本の教育 を見ていると湧いてきます。もつと, 教育の多様性を 認めていくことも必要なのではないか, そんなことを 感じています。

\section{討 論}

（有川）神山さん，岩浪さんに，司会の私から質問し たいことがあります。障害の診断を受ける前と，受け た後で，ご自身の生活の何が変わったのかを教えてい ただきたいと思います。

（神山）私は今から 15 年ほど前に診断を受けました。 教員になってからのことです。久里浜の研修所で研修 を受けていた時のことです。研修で出される資料が膨 大で，ついていけなかった。そこで「もう，研修を辞 めて岐阜に戻ろう」と, 研修担当の先生にお話をした のです。そうしたら，検査してみようということにな りました。結果は, 音読が小学 2 年生程度, 文字を読 むのは小学 5 年生程度という結果がでました。これで は厳しいことがわかり，どの様な支援があれば研修を 続けていけるか，考えていきましょうということにな りました。診断を受けることで，配慮がもらえること になった。「診断＝配慮」ということで，とても生き やすくなりました。職場でも, 職員間で交わされる書 類はデータにしたものを，サーバにあげてもらえるよ うになりました。とても助かっています。

逆に小, 中学校に教育相談で回っていると, 現場の 子どもたちには，私が使っている文章読みあげソフト が，使えていません。子ども達は，診断をもらってい るにもかかわらず，彼らに合った支援は提供されてい ない。相談内容も, どうすれば「普通に学ばせられる か」というものが多いのです。これは違うと思います。 とても違和感を持っています。

（岩浪）それまでは，自分が抱える違和感に，ただモ ヤモヤした感覚がずっと続いていました。それが，診 断が出たことで, ようやく安心しました。「やった着 地点が見つかった」，そんな感じがしました。親も， ようやく，その診断が出たことで障害の理解をするよ うになりました。

（有川）周佐さんにお聞きします。周佐さんは，今で も歩行訓練を受けていると，お聞きしました。

私, 以前, 就学前の身体障害の子どもたちの施設で 働いていたことがあったのですが，その中で 5 年間か けて，ようやくクラッチを使って 5 メートル歩けるよ うになった子どもがいました。もちろん，その 5 メー トルが, 様々な身体機能を促進, 維持していくために 必要だということはわかりました。

ところが, これが学校に行くと, ちょつと視点が変 わってしまっていたのです。「少しでも障害のない人 と同じ動作ができるようになる」ことが求められてい 
たのです。少し歩けるということだけで，なかなか車 椅子を使った生活をさせようとしない。そういう経験 をされたことはありませんでしたか。

(周佐) あります。高等部までは, 歩行器を使って 「歩きましょう」と言われ,ずっと歩かされてきまし た。けれども, 高等部 3 年生の 2 学期に入ると「もう 社会に出るのだから, 今度は車椅子に乗りましょう」 と言われた。この時，「あなたはもう，歩けないのだ」 という烙印を押されたような気持ちになりました。車 椅子の練習は, 高等部の時から始めたので, 今でも車 椅子の漕ぎ方は, 下手くそです。どうせ社会に出てか ら必要になるのだったら, 初めから車椅子の練習をさ せてくれればよかったのにと思っています。

（フロア 1） 神山先生に 2 点ほどお伺いしたい。1つ は，採用試験を受けられた時には，特別な配慮はな かったと思うのですが，採用試験をどう突破したので すか。もう 1 つは, 日常に扔てて困っていることはど のようなことがありますか。

（神山）大学入試は，社会人枠でしたので，面接と口 頭試問だけでした。でも教員採用試験は，そういうわ けにはいかない。3 年かかりましたが，ひたすら勉強 しました。

過去の問題や他府県の採用試験の問題をすべて見て, 「この字面がいっぱい並ぶ問題は, この答え」と丸暗 記して臨みました。あとは, 聞かれてもいない問題に ついても, 自分が一生懸命勉強してきたことを伝える ために, 裏面の白紙に知っていること, 自分が経験し てきたことをいっぱい書き綴りました。自分はこれだ けの知識をもっているということを，いっぱい書いて， 熱意をアピールしました。

もう1つの質問についてですが, 困ることは非常に 少なくはなっています。ただ個人情報に関するものが 話題となるときは，録音や，データではもらえない。 今でもアナログで対応しています。これは, 守秘義務 がありますので，仕方がないと思います。

日常で困ることは, 役場の空口で, 所定の様式に, その場で書くことができない。事前に 1 回行って用紙 をもらい, それを持ち帰って, 記入して, また別の日 に持っていく。そういうところは困っています。

（フロア 2) 私は特別支援学校の教員をしています。 今日，打話を聞いて，自分が良かれと思ってやったこ とが，実は生きづらさを生んでいたり，社会に出て 困ったりする原因を作っていたことを知りました。や はり，そこにコミュニケーションがないということが， 一番危険なことだと感じました。
そこで，質問です。どの様なコミュニケーションが あれば，こうした問題は起こらないと㧍考えですか。 例えば，「嫌だ」「いらない」などのような伝達などが あると思うのですが，いかがでしょうか。

（神山）「聞いていただける」という姿勢があるだけ で，気持ちはとても楽になります。まずは「こちらに 配慮してもらえている」という気持ちが抱けるだけで すごく楽になるのです。ただ, 逆に私の生きやすさに は，直にはつながらないこともある。それはなかなか 言いにくいです。

（岩浪）私は, 提供される支援と, 自分が求める支援 が違うときは例を出して伝えるようにしています。 「サボテンにあげる水と, 普通のお花にあげる水の量 は違う。普通のお花に, サボテンに必要な水の量をあ げれば, 当然, 花は枯れてしまいますし, 逆にサボテ ンに普通の花に必要な水程度しかあげなければ, それ も枯れてしまいます」などと伝えます。そうして，日 頃から相互の違いをまず認めていくことが必要だと思 います。

（周佐）私たちは，身体の障害が重くなればなるほど， 相手が良かれと思ってやってくれていることを，断れ ない。断ってしまったら，この人からは，もう援助が 受けられなくなると思っています。だから，我慢して 領いてしまいます。

今，ピアカウンセリングを受けています。そこで言 われることは「断っても，その人は，いなくならない から大丈夫だ」ということを教わりました。けれど も養護学校の時には, 断れなかった。先生も「がん ばってるね，いい子だね」と言うので，いい子でいな くていけないと思っていました。だから，断るなんて できないのです。でも最近分かったことは「断ってい いのだ，それで喧嘩になったのなら，仲直りすればい い」と思うようになりました。もし仲直りできなかっ たら，それくらいの怒りだったと考えればよいのだと わかってきました。こういうやりとりを，障害のない 人たちは小学生から, 高校生の頃までに, 友達や親と の間で経験しているようです。だけれども, 養護学校 だと，障害者は天使みたいな扱われ方なので，私たち もすごくいい子でいなければならないと思っていまし た。

$1 つ$, 私からも皆さんにお聞きしたいのですが, 「お前たちは考える力がない」ってよく言われます。 先生の立場からだと, この考える力を, どのように教 えていますか。「考えるってこういうことだよ」と， 相方に教えたいのですが，それが伝わらない。考えた 
ことがないのです。学校の先生であれば，それをどう 教えているのですか。

（フロア 2 ） 方法は 1つではないと思います。あくま で私個人のやり方ですけども，正解を伝えて，こうだ よと言うのではなく，一緒に体験したことを振り返る。 それを日々の中で繰り返していくことが 1 つなのでは ないかと思います。

（有川）シンポジストの神山さんも，特別支援学校の 教員の立場です。今の質問について何かありますか。

（神山）実に痛いとこ突かれたなという気がします。 今, 学校教育では「教科書 “を” 教える」先生が多く なっていると感じています。「教科書 “で”教える」 先生が少なくなっています。指導書を片手に授業を進 める先生もいます。まず教員の方が知識偏重型になり, 自ら切り開いていく力を失っているのではないでしょ うか。今の質問を，多くの先生方に聞いていただけて よかったと思います。本当に「考元ろ，考元ろ」では なく,「考える力をつける教育」を私たち自身がして いかなければならないはすです。

（周佐）もう 1 つ，フロアに質問があります。養護学 校だと, 少数, あるいは 1 対 1 の授業が多くありまし た。ですので，今でも多くの人たちの中に，汸つんと 1 人いると，みんなに問われているのか，私個人に向 けられているかがよく分からない。皆さんはそういう 経験はありませんか。

（有川）なかなか，回答がないようですので私から。 実は，周佐さんは，打ち合わせの時からこの話をしき りにされていました。彼が何を言いたいかというと， ずっと自分たちは個別の教育を手厚く受けてきた。そ の代わりに「みんな」という考方方を学べなかった。

「みんな」という問いかけは，障害のある自分たちに とっては，特別な「ことば」だと言うのです。

逆に私たちは, 常に「みんな」というものからこぼ れ落ちないように教育を受けてきました。それを強要 され，必死で「みんな」の中に留まろうとしてきまし た。だから，「みんな」からこぼれ落ちてしまうこと は，考えたくもないし，こぼれてしまっている人達の ことを考えても来なかった。これはこれで，なかなか
辛いものがありました。この感覚の違いについては, 障害のある人達と, 障害のない人たちの双方で共通理 解が必要なところかなと思います。

（フロア３） 今日のシンポジウムのタイトルが，「私 たち抜きで，私たちのことを決めるな」ということで すが，自分のことを自分以外の人から勝手に決められ たという，このスローガンに反するようなことをされ た経験があれば，教えていただけませんか。

(岩浪）よくあります。先生にというよりは, 家族が 自分の意思とは関係なくいろいろと先回りをしてやっ てしまう。また，社会人とはこうあるべきだという枠 を勝手にはめられてしまい, とても困りました。

（周佐） ぞうしてもへルパーさんの時間の都合で，自 分の希望を変えなければいけないことがあります。必 ず，ヘルパーさんと一緒に決めなければならない。こ れが，ストレスになる時もあります。反対に周りの人 に昔から決められてきたので「あなたが決めなさい」 と言われると，それはそれで布くなる。自分で決める ことも怖いし, 決められてばかりだと嫌なところもあ ります。

（神山） 今現在でも，ディスレクシアだからといって 手帳がもらえるかというと, そうではない。仮に, 手 帳がもらえれば支援をもらえるかというと，そうでも ない。街の中には, 何の配慮もない文字が並んでいる 状態はきっと変わりません。そうなると結局は, 「読 めるようになった方がよいから」ということになって しまう。

読めなくても困らない環境整備があれば，こういう 考え方自体がなくなると思います。「普通になれ」と いうことではなく, 普通に暮らせる環境整備を, お互 いに顔を合わせて模索していくことが「合理的配慮」 に繋がるのではないかと思います。

注）本シンポジウムの内容は, 話題提供者が学んだ当 時の教育制度をもとに構成している。したがって本 稿に扔いても,「養護学校」という表記を, そのま ま使用している。 